\title{
Faktor Penyebab Waktu Tunggu Lama di Pelayanan Instalasi Farmasi Rawat Jalan RSUD Blambangan
}

\section{Factors Causing Long Waiting Time on Outpatient Pharmacy Department Services at Blambangan General Hospital}

\author{
Heri Purwanto', Indiati', Taufiq Hidayat ${ }^{3}$ \\ ${ }^{1}$ Program Studi Magister Manajemen Rumah Sakit Fakultas Kedokteran Universitas Brawijaya Malang \\ ${ }^{2}$ Rumah Sakit Umum Daerah Blambangan Banyuwangi \\ ${ }^{3}$ Rumah Sakit Angkatan Laut HUDA Genteng Banyuwangi
}

\begin{abstract}
ABSTRAK
Instalasi Farmasi RSUD Blambangan merupakan revenue center bagi Rumah Sakit. Waktu tunggu pelayanan Apotek Rawat Jalan RSUD Blambangan belum sesuai Standar Pelayanan Minimal Departemen Kesehatan Republik Indonesia. Penelitian ini bertujuan mengidentifikasi, menentukan akar permasalahan dan menentukan alternatif solusi atas permasalahan waktu tunggu pelayanan Instalasi Farmasi. Metode untuk mengidentifikasi akar masalah digunakan analisis tulang ikan (fish bone ishikawa) dan dilakukan Focus Group Discussion. Untuk memprioritaskan akar masalah ini digunakan metode USG (Urgency, Serious, and Growth). Metode untuk alternatif solusi adalah Mc. Namara. Hasil penelitian menunjukan 3 akar masalah yaitu proses screening lama dan satu loket, jauhnya Poli Penyakit Dalam sebagai resep terbanyak, tempat penerimaan resep BPSS dan umum jadi satu loket. Solusi terpilih adalah menambah tenaga screening dan loket antrian. Sebelum menambah tenaga screening dan loket antrian, waktu tunggu rata-rata obat jadi 70,81 menit, racikan 139,85 menit. Setelah solusi waktu tunggu rata-rata obat jadi 63,88 menit, racikan 108 menit. Hasil solusi waktu tunggu mengalami penurunan, obat jadi 7 menit, racikan 31 menit.
\end{abstract}

Kata Kunci: Antrian, instalasi farmasi, loket antrian, screening, waktu tunggu

\begin{abstract}
Pharmacy Department of Blambangan Hospital is a revenue center for the hospital. The waiting time of outpatient pharmacy services Blambangan Hospital has not met the Minimum Service Standard from Ministry of Health of Republic Indonesia. This study aims to identify, determine root causes, and determine alternative solutions to the problems of waiting times on pharmacy services. The methods used to identify the root cause were fishbone analysis (fishbone Ishikawa) and Focus Group Discussion. USG method (Urgency, Serious, and Growth) was used to prioritize the root of problem, and Mc. Namara theory was used to find alternative solutions. The results show three roots of problem, namely long screening process and one counter availability, the distance of internal disease unit as the biggest prescription acceptance, BPJS and general prescription acceptance is in one counter. The highest total score of the solution is to increase the screening personnel and queuing counter. Before adding screening personnel and queuing counter, average medication service waiting time was 70.81 minutes, compounding medicine was 139.85 minutes. After the solution the average medication service waiting time was 63.88 minutes, compounding medicine was 108 minutes. The waiting time has decreased, medication service is 7 minutes faster and compounding medicine service is 31 minutes faster.
\end{abstract}

Keywords: Pharmacy, queue, queuing counter, screening, waiting time

Jurnal Kedokteran Brawijaya, Vol. 28, Suplemen No. 2, 2015; Korespondensi: Heri Purwanto. Program Studi Magister Manajemen Rumah Sakit Fakultas Kedokteran Universitas Brawijaya Malang, Jl. Veteran Malang 65145 Tel. (0341) 569117 Email: purwantoheridr@gmail.com 


\section{PENDAHULUAN}

Instalasi Farmasi merupakan bagian yang tidak dapat dipisahkan dari sistem pelayanan kesehatan rumah sakit yang utuh. Pelayanan di rumah sakit berorientasi kepada pelayanan pasien, penyediaan obat yang bermutu dan terjangkau bagi semua lapisan masyarakat. Instalasi Farmasi RSUD Blambangan merupakan revenue center bagi Rumah Sakit. Data menunjukkan 51\% pendapatan RSUD Blambangan diperoleh dari instalasi farmasi (1). Sebagai satu revenue center, pemeliharaan mutu pelayanan obat pada Instalasi Farmasi perlu mendapatkan perhatian.

Berdasarkan kunjungan rawat jalan dan jumlah resep yang masuk Apotek Rawat Jalan, Klinik Penyakit Dalam yang mempunyai kunjungan terbesar, diikuti Bedah Umum dan Poli Syaraf. Jumlah resep pasien BPJS sekitar $74 \%$, pasien umum 26\%. Jumlah rata-rata resep peak hours jam 10.00 WIB sampai 13.00 WIB adalah 150 resep. Setiap resep yang diterima Apotek Rawat Jalan melalui alur pelayanan. Pelayanan resep Instalasi Rawat Jalan menggunakan sistem antrian atau loket hanya satu dan screening oleh satu orang. Komputer yang digunakan hanya 2. Studi pendahuluan menunjukkan waktu tunggu antrian ratarata obat jadi 70,81 menit, racikan 139,85 menit.

Standar Pelayanan Minimal (SPM) pelayanan farmasi sesuai Depkes Republik Indonesia adalah waktu tunggu obat jadi $\leq 30$ menit, obat racikan $\leq 60$ menit, tidak adanya kejadian kesalahan pemberian obat $100 \%$, kepuasan pelangan $\geq 80 \%$ dan penulisan resep sesuai formularium $100 \%(2)$.

Menunggu merupakan suatu interaksi pertama kali yang menghubungkan pelanggan dengan suatu proses layanan. Pelanggan menganggap menunggu suatu antrian adalah mahal, membuat ketidak nyamanan dan frustasi (stres). Menunggu antrian lama menyebabkan persepsi negatip terhadap produksi, kualitas pelayanan dan kepuasan pelanggan (3). Harapan dari pelanggan atau pasien terhadap rumah sakit adalah untuk mendapatkan pelayanan kesehatan yang berkualitas dan handal. Pasien yang datang berobat ke rumah sakit menginginkan segera mendapatkan pelayanan tanpa harus menunggu dalam waktu yang lama (4). Penelitian ini bertujuan mengidentifikasi waktu tunggu pelayanan, menentukan akar permasalahan kenapa waktu tunggu pelayanan resep lebih lama dari SPM, menentukan alternatif solusi atas permasalahanwaktu tunggu pelayanan Instalasi Farmasi Rawat Jalan RSUD Blambangan.

\section{METODE}

Metode yang digunakan adalah menggunakan Focused Group Discussion (FGD) dengan peserta 30 orang yaitu pihak manajemen, instalasi farmasi dan instalasi rawat jalan. Diskusi dilakukan dalam dua tahap. Tahap pertama berdiskusi faktor-faktor penyebab waktu tunggu pelayanan farmasi lama, kemudian dianalisis dengan menggunakan diagram fishbone. Setelah ditemukan beberapa akar masalah, dibatasi 3 akar masalah mengunakan metode USG. Hasil diskusi pertama didiskusikan kembali dengan seluruh perserta pada tahap kedua. Diambil prioritas masalah dengan metode USG (Urgency, Seriousness, Growth) dengan nilai skala 1-5. Masalah yang terpilih selanjutnya didiskusikan alternatif pemecahan dan diambil prioritas pemecahan masalah dengan metode tapisan Mc.Namara.

\section{HASIL}

Berdasarkan FGD bersama manajemen rumah sakit RSUD Blambangan Banyuwangi, diperoleh akar permasalahan penyebab waktu tunggu lama di instalasi farmasi rawat jalan RSU Blambangan. Gambar 1 menyajikan berbagai akar masalah yang ditemukan penyebab waktu tunggu antrian lama di instalasi farmasi rawat jalan.

Setelah ditemukan beberapa akar masalah, dibatasi 3 akar masalah mengunakan metode USG (Urgency, Serious, and Growth) yaitu: proses screening lama dan satu loket, jauhnya Poli Penyakit Dalam sebagai resep terbanyak, tempat penerimaan resep BPJS dan umum pada satu loket (Tabel 2).

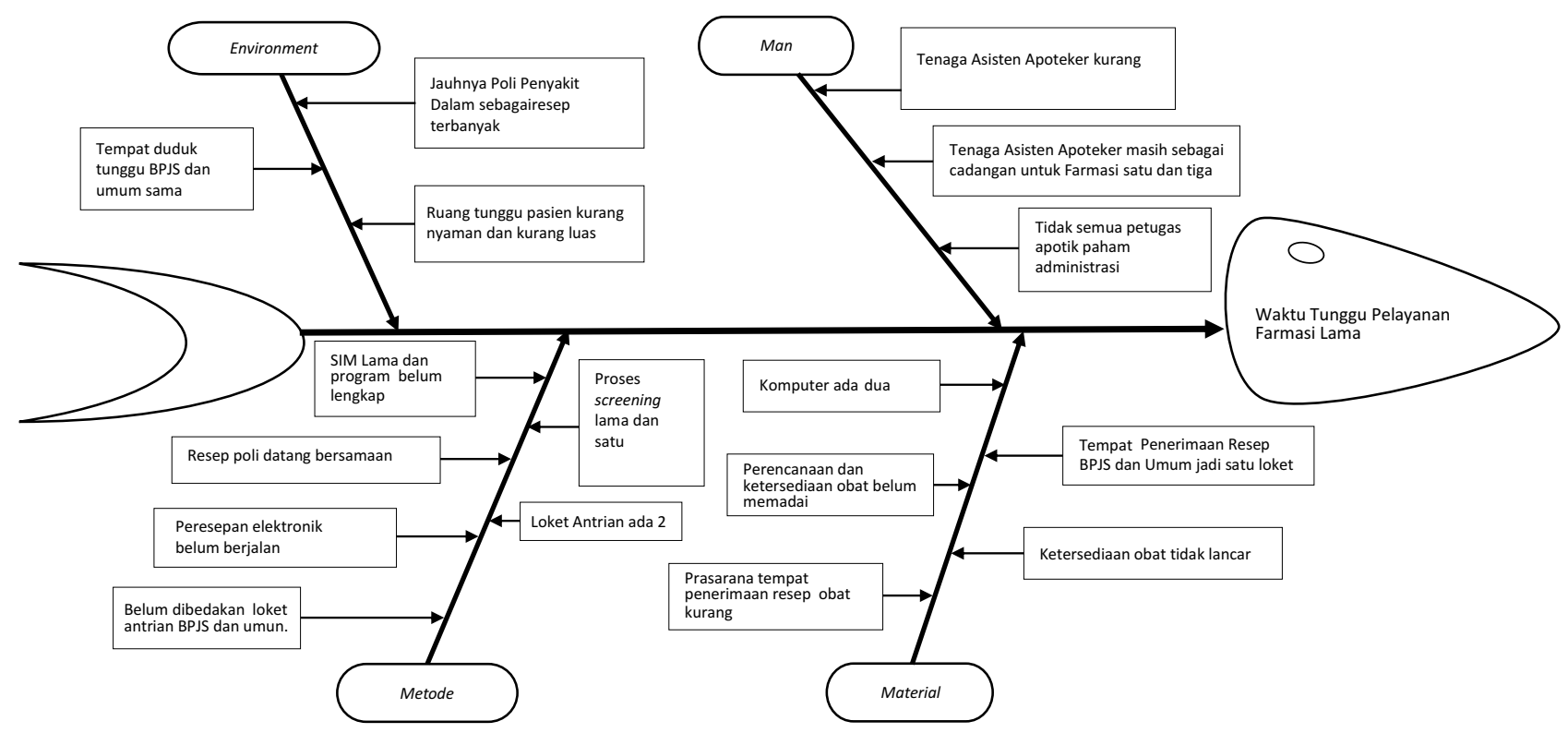

Gambar 1. Diagram FishBone Ishikawa 
Tabel 2. Prioritas akar masalah

\begin{tabular}{|c|c|c|c|c|c|c|}
\hline No. & Akar Masalah & $\mathbf{U}$ & $\mathbf{S}$ & G & Total & Ranking \\
\hline 1. & Tenaga Asisten Apoteker kurang. & 2 & 2 & 1 & 4 & XIV \\
\hline 2. & $\begin{array}{l}\text { Tenaga Asisten Apoteker masih } \\
\text { sebagai cadangan untuk farmasi } \\
1 \text { dan3. }\end{array}$ & 3 & 2 & 1 & 6 & XIII \\
\hline 3. & $\begin{array}{l}\text { Tidak semua petugas apotek } \\
\text { paham administrasi. }\end{array}$ & 2 & 2 & 2 & 8 & $X I$ \\
\hline 4. & $\begin{array}{l}\text { Tempat penerimaan resepBPJS } \\
\text { dan umum jadi satu loket. }\end{array}$ & 5 & 5 & 3 & 75 & III \\
\hline 5. & Ketersediaan obat tidak lancar. & 2 & 2 & 3 & 12 & $x$ \\
\hline 6 & Komputer ada dua. & 3 & 2 & 2 & 12 & IX \\
\hline 7. & $\begin{array}{l}\text { Proses screening lama dan satu } \\
\text { loket. }\end{array}$ & 5 & 5 & 4 & 100 & 1 \\
\hline 8 & $\begin{array}{l}\text { Prasarana tempat penerimaan } \\
\text { obat kurang. }\end{array}$ & 3 & 4 & 4 & 48 & V \\
\hline 9 & $\begin{array}{l}\text { Peresepan elektronik belum } \\
\text { berjalan. }\end{array}$ & 2 & 2 & 2 & 8 & XII \\
\hline 10 & $\begin{array}{l}\text { SIM lambat danprogram belum } \\
\text { lengkap. }\end{array}$ & 3 & 3 & 3 & 27 & VII \\
\hline 11 & $\begin{array}{l}\text { Tempat duduk tunggu BPJS dan } \\
\text { umum sama. }\end{array}$ & 2 & 3 & 3 & 18 & VIII \\
\hline 12 & $\begin{array}{l}\text { Jauhnya Poli Penyakit Dalam } \\
\text { sebagai resep terbanyak. }\end{array}$ & 5 & 4 & 4 & 80 & II \\
\hline 13 & $\begin{array}{l}\text { Ruang tunggu pasien kurang } \\
\text { nyaman dan kurang luas. }\end{array}$ & 4 & 3 & 3 & 36 & VI \\
\hline 14 & Resep poli datang bersamaan. & 4 & 4 & 4 & 64 & IV \\
\hline
\end{tabular}

Sumber: Hasil FGD 10 September 2014

Penyelesaian masalah adalah suatu kegiatan mencari dan menghilangkan akar masalah. Bukan gejala masalah yang diselesaikan, tetapi akar masalahnya yang diatasi, agar tidak berulang kembali. Metode untuk menemukan alternatif solusi yang akan dipakai adalah Mc. Namara.

Hasil FGD pada tangal 10 September 2014 menghasilkan beberapa solusi yaitu: membedakan loket umum dan BPJS, menambah tenaga screening dan loket antrian, menambah komputer, memfokuskan tenaga khusus farmasi rawat jalan, sistem peresepan elektronik, membuka pelayanan obat di Poli Penyakit Dalam (Tabel 3). Setiap alternatif solusi di skor antara 1-5 dari masingmasing anggota FGD, kemudian dijumlahkan. Total skor yang tertinggi merupakan pilihan alternatif solusi.

\section{Tabel 3. Hasil skoring alternatif solusi}

\begin{tabular}{|c|c|c|c|c|c|c|}
\hline No & Alternatif Solusi & Efektifitas & $\begin{array}{c}\text { Efisiensi } \\
\text { (biaya) }\end{array}$ & Kemudahan & Total & Ket. \\
\hline 1. & $\begin{array}{l}\text { Membedakan loket umum } \\
\text { dan BPJS }\end{array}$ & 4 & 4 & 4 & 64 & II \\
\hline 2. & $\begin{array}{l}\text { Menambah tenaga } \\
\text { screening dan loket antrian }\end{array}$ & 5 & 5 & 5 & 125 & 1 \\
\hline 3. & Menambah computer & 2 & 1 & 3 & 6 & V \\
\hline 4. & $\begin{array}{l}\text { Memfokuskan tenaga } \\
\text { khusus Farmasi Rawat Jalan }\end{array}$ & 3 & 3 & 3 & 27 & IV \\
\hline 5. & Sistem Peresepan Elektronik & 1 & 2 & 1 & 2 & VI \\
\hline 6. & $\begin{array}{l}\text { Membuka pelayanan obat } \\
\text { di Poli Penyakit Dalam }\end{array}$ & 5 & 4 & 3 & 60 & III \\
\hline
\end{tabular}

Sumber: Hasil FGD 10 september 2014

Keterangan: Skor 1: sangat tidak efektif/ sangat tidak murah/ sangat tidak mudah/ sangat tidak mampu. Skor 2: tidak efektif/ tidak murah/ tidak mudah/ tidak mampu. Skor 3: cukup efektif/ cukup murah/ cukup mudah/ cukup mampu. Skor 4: efektif/ murah/ mudah/ mampu. Skor 5: sangat efektif/sangat murah/sangat mudah/sangat mampu.
Alternatif solusi yang mempunyai nilai total tinggi adalah menambah tenaga screening dan loket antrian. Pola antrian dapat dipecah dan memperpendek waktu screening dan memperpendek waktu tunggu antrian di Pelayanan Farmasi Rawat Jalan. Solusi yang mempunyai nilai total tertinggi adalah menambah tenaga screening dan loket antrian. Solusi pertama ini akan segera dilaksanakan oleh Apotek Rawat Jalan, untuk mengurangi waktu tunggu pelayanan resep Apotek Rawat Jalan.

Sebelum solusi dilaksanakan, jumlah tenaga screening dan loket masih satu. Tanggal 17 September 2014 dilakukanpengamatan waktu tunggu pelayanan resep Apotek Rawat Jalan. Waktu pengamatan pada saat peak hours, hasil pengamatan waktu tunggu pelayanan resep rata-rata obat racikan 139,85 menit, obat jadi 70,81 menit. Waktu tunggu ini belum memenuhi target yang ditetapkan.

Sesuai dengan rencana, tanggal 2 Oktober 2014 ditetapkan penambahan tenaga screening dan loket antrian menjadi dua. Pada hari tersebut dilakukan pengamatan waktu tunggu pelayanan resep Apotek Rawat Jalan. Waktu pengamatan pada saat peak hours, hasil pengamatan waktu tunggu pelayanan resep sesudah solusi rata-rata obat racikan 108 menit, obat jadi 63,88 menit.

Sebelum menambah tenaga screening dan loket antrian, waktu tunggu rata-rata obat jadi 70,81 menit, racikan 139,85 menit. Setelah melaksanakan solusi waktu tunggu rata-rata obat jadi 63,88 menit, racikan 108 menit. Hal ini menunjukkan sesudah solusi waktu tunggu mengalami penurunan yaitu waktu tungguobat jadi 7 menit dan obat racikan 31 menit. Penurunan waktu tersebut tunggu belum memenuhi target yang ditetapkan Departemen Kesehatan Republik Indonesia yaitu obat jadi $\leq 30$ menit dan racikan $\leq 60$ menit.

\section{DISKUSI}

Lamanya waktu untuk menunggu pelayanan di Instalasi Farmasi Rawat Jalan merupakan salah satu aspek penting yang mempengaruhi kepuasan pasien. Waktu tunggu mempunyai 4 dimensi yaitu obyektif (actual waiting time), subjektif/persepsi (estimasi lamanya menunggu), kognitif (evaluasi proses menunggu), afektif (respon terhadap proses menunggu). Kepuasan yang terkait waktu tunggu dapat dipengaruhi expected waiting time (EWT), perceived waiting time (PWT), actual waiting time (AWT) dan disconfirmation $(5,6)$.

Tiga akar masalah yang penting waktu tunggu lama berdasarkan FGD di Instalasi Farmasi Rawat Jalan RSUD Blambangan yaitu: proses screening lama dan satu loket, jauhnya lokasi Poli Penyakit Dalam sebagai resep terbanyak, tempat penerimaan resep BPJS dan umum yang digabungkan dalam satu loket. Hal ini sesuai dengan temuan Aditama bahwa faktor yang mempengaruhi pelayanan farmasi adalah sistem antrian dan letak pelayanan farmasi terhadap pelayananan poli rawat jalan (7). Pada rumah sakit tempat kajian ditemukan letak Poli Penyakit Dalam ada dilantai 2 sedangkan Instalasi Farmasi di lantai satu menunjukkan permasalahan jarak sebagai faktor yang mempengaruhi antrian.

Menurut penelitian Syukraa kebutuhan Asisten Apoteker dengan jumlah resep 700 adalah 34 Asisten Apoteker. Metode perhitungan tenaga Instalasi Farmasi Rawat Jalan Rumah Sakit yang digunakan mengunakan metode WISN 
(Work Load Indicators of Staffing Needs). Berdasarkan data saat penelitian menunjukkan kekurangan tenaga Apotek Rawat Jalan masih kurang 4 orang Asisten Apoteker.

Sistem antrian di Instalasi Farmasi Rawat Jalan RSUD Blambangan hanya satu loket. Menurut penelitian Susilowati tentang pengembangan model sistem antrian resep pada Farmasi Rawat Jalan Rumah Sakit Haji Jakartamenunjukkan bahwa semakin banyak loket antrian akan mempercepat proses waktu tunggu pelayanan. Umumnya sistem antrian menganut prinsip yang datang duluan akan dilayani terlebih dahulu (first come, first served) (8)

Ada dua hal penting dalam mengelola instalasi farmasi yaitu staf dan tata letak fasilitas bangunan fisik. Selain itu terdapat faktor-faktor kunci yang perlu diperhatikan dalam pelayanan resep meliputi pelayanan yang cepat dan ramah, jaminan tersedianya obat dengan kualitas baik harga kompetitif, adanya kerja sama dengan unsur lain dirumah sakit seperti dokter dan perawat, serta kenyamanan ruang tunggu (7). Kemudahan akses untuk memperoleh obat dan ketersediaan obat adalah faktorfaktor pelayanan farmasi yang dilaporkan mempengaruhi

\section{DAFTAR PUSTAKA}

1. Hidayat T. Laporan Tahunan 2013 RSUD Blambangan Banyuwangi. Banyuwangi: RSUD Blambangan; 2013.

2. Febriawati H. Manajemen Logistik Farmasi Rumah Sakit. Yogyakarta: Gosyen Publishing; 2013.

3. Ryan $\mathrm{G}$ and Valverde M. Waiting Online: A Review and Research Agenda. Internet Research. 2003; 13(3):195-205.

4. Purwastuti CR. Analisis Faktor-faktor Pelayanan Farmasi yang Memprediksi Keputusan Beli Obat Ulang dengan Persepsi Pasien Klinik Umum di Unit Rawat Jalan RS Telogorejo Semarang. [Tesis]. Universitas Diponegoro, Semarang. 2005.

5. Pruyn A and Smidts A. Effects of Waiting on the Satisfaction with the Service: Beyond Objective Time Measures. International Journal of Research in Marketing. 1998;15(4):321-334.

6. Davis MM and Heineke J. How Disconfirmation, kesinambungan pengobatan (9). Penelitian yang dilakukan Kusmunarini dan Bhaskara menunjukan keunggulan resep elektronik lebih mengutungkan dibandingkan resep manual dan mengurangi waktu tunggu pelayanan Instalasi Farmasi Rumah Sakit (10).

Berdasarkan hasil FGD RSUD Blambangan menambah loket dan tenaga. Setelah melaksanakan solusi menambah tenaga screening dan loket antrian, waktu tunggu mengalami penurunan, namun belum memenuhi target yang ditetapkan Departemen Kesehatan Republik Indonesia yaitu obat jadi $\leq 30$ menit dan obat racikan $\leq 60$ menit.

Hal ini terjadi karena masih terjadi penumpukan resep dokter bersamaan. Resep datang bersamaan menambah waktu tunggu antrian. Intervensi sistem pelayanan dokter perlu dipertimbankan yaitu pemeriksaan pelayanan pasien lebih awal. Faktor-faktor lain yang mungkin mempengaruhi selain faktor antrian adalah jumlah pelayanan, komputer yang kurang dan software yang lambat, ketersediaan obat tidak lancar, tidak semua petugas paham administrasi dan sistem administrasi BPJS yang rumit.

Perception and Actual Waiting Times Impact Customer Satisfaction. International Journal of Service Industry Management. 1998; 9(1): 64-73.

7. Aditama TY. Pelayanan Farmasi dalam Manajemen Administrasi Rumah Sakit. Jakarta: UI Press; 2002.

8. Susilowati H. Pengembangan Model Sistem Antrian Resep pada Farmasi Rawat Jalan Rumah Sakit Haji Jakarta 2002. [Tesis]. Universitas Indonesia, Jakarta. 2002.

9. Ifmaily. Analisis Pengaruh Persepsi Layanan Farmasipaien Unit Rawat Jalan Terhadap Minat Beli Obat Ulang di Instalasi Farmasi RSI Ibnu Sina-Yarsi 2006. [Tesis]. Universitas Diponegoro, Semarang. 2006.

10. Putu Kusmunarini. Penerimaan Dokter Dan Waktu Tunggu Pada Peresepan Elektronik Dibandingkan Peresepan Manual. Jurnal Manajemen Pelayanan Kesehatan. 2011;14:133-138. 